\title{
Water Budgets to Schedule Irrigation for Vegetables
}

\author{
Doyle A. Smittle \\ and W. Lamar Dickens
}

\begin{abstract}
Additional index words. snap bean, summer squash, muskmelon, sweetpotato, turnip, mustard, pan evaporation, water balance models, soil water tension
\end{abstract}

Summary. Instrumented rainfall- and groundwater-protected irrigation shelters were used to establish relationships (daily crop factors) between pan evaporation and daily water use for several vegetables. Use of these daily crop factors (water use/pan evaporation) and pan evaporation data for scheduling irrigations are described. Snap bean (Phaseolus vulgaris L.) is used to illustrate irrigation scheduling by this method. A table of the model output with columnar headings of age, root depth, date, pan evaporation, crop factor, daily water use, cumulative water use, allowable water use, rainfall, and irrigation is presented. When irrigation was applied according to the model, soil water tension was held below $25 \mathrm{db}$ at 6 -inch $(15-\mathrm{cm})$ soil depth. With varying irrigation rates under a line-source irrigation system, marketable pod yields were maximized at $100 \%$ of the model rate. Marketable yields of summer squash also were maximized when irrigation was applied at $100 \%$ of the model rate. Marketable yields of sweetpotato were not affected by irrigation rates ranging from $1 \%$ to $177 \%$ of the model rate. ase of use and availability of measurement data are important criteria in the selection of a method for scheduling irrigations. Soil and plant water measurements have been used to determine when to irrigate, but they have not been used extensively for irrigation scheduling models (Bruce et al., 1980; Haise and 
Hagan, 1967; Hansen et al., 1980; Stegman et al., 1980).

Estimation of evapotranspiration (ET) by climate based methods often is used in irrigation scheduling models, but calibration for specific crops and local conditions often has been required. Climate-based methods of estimating ET incorporate measure ments of air temperature, air move ment, solar radiation, and relative humidity. Pan evaporation $\left(E_{p}\right)$ combines these climatic conditions and has been used to estimate ET (Jensen and Middleton, 1970). A single adjustment of $E_{0}$ data for estimation of ET was used, but the single-crop factor value often caused excessive water applications during the early stages of crop growth when water use by the crop was low.

M odel development. The irrigation scheduling model uses the water balance technique described by Stegman et al. (1980). The water balance technique simply states that irrigation is applied when the sum of the daily soil water depletions is equal to the allowable soil water depletion. The irrigation scheduling model for snap beans (Smittle et al., 1990) is used to illustrate the development of a simple irrigation scheduling model.

The allowable soil water depletion is determined by the volume of the rhizosphere (root zone) and the fraction of the available water to be removed from it before irrigating. Root growth began 6 days after planting snap bean seeds 1 inch deep, then the root depth increased one-half inch per day until a maximum root depth was attained. Maximum root depth for snap bean is $\approx 16$ inches in the Coastal Plain of the southeastern United States (Bruce et al., 1980), but may exceed 36 to 48 inches in areas where physical or chemical conditions of the soil do not inhibit root growth (Mack and Varseveld, 1982). Soil compaction and tillage methods may alter dramatically the maximum root depth. Although our data generally show that yields and water-use efficiency were maximized when snap beans were irrigated at 25 cb (Stansell and Smittle, 1980), we allowed a depletion of $50 \%$ of the available soil water (ASW) due to substantial water use at soil water contents above field capacity (Hansen et al., 1980). The allowable soil water depletion (inches) is calculated as:

$$
0.5(a-4) \times 0.5 \mathrm{ASW}
$$

where $a$ is the number of days after planting.

The sum of the daily water deple tions requires the addition of the daily $E T$, calculated as $E_{p}$ times the daily crop factor value, and the subtraction of the rainfall since the last irrigation, or rainfall in excess of the allowable soil water depletion. Daily crop factor values for snap beans irrigated at soil water tensions of $25 \mathrm{cb}$ (Stansell and Smittle, 1980) are calculated as:

$$
\text { Daily } E T=E_{p}(0.31+0.01 a) \text {. }
$$

The irrigation scheduling model for snap beans is represented by the equation:

$$
\begin{aligned}
& 0.5(a-4) \times 0.5 A S W=D_{a-1}+ \\
& {\left[E^{p}(0.31+0.01 a)-P-I\right]_{a^{\prime}}}
\end{aligned}
$$

where crop age (a) is days after planting; effective root depth is $0.5(a-4)$ with a maximum of 16 inches; usable water (inch $^{3}$ per inch of soil) is 0.5 ASW, soil water deficit on the previous day is $D_{\text {; }}$; daily depletion is $E_{\text {times }}$ $0.01 a+0.31$; rainfall (inches) is $P$; and irrigation (inches) is I.

Models also have been developed for summer squash, sweetpotato, greens (turnip and mustard), and muskmelon. The irrigation model for summer squash is represented by the equation:

$$
\begin{aligned}
& 0.5(a-4) \times 0.5 A S W=D_{a-1}+ \\
& {\left[E_{p}(0.14+0.015 a)-P-I\right]_{a}}
\end{aligned}
$$

where the maximum root depth is 15 inches. The irrigation model for sweetpotato is represented by the equation:

$3+0.5(\mathrm{a}-3) \times 0.5 \mathrm{ASW}=\mathrm{D}_{\mathrm{a}-1}+$ $\left[E_{p}\left(0.12+0.023 a-0.00019 a^{2}\right)-P-I\right]_{a}$

where the maximum root depth is 12 inches. The irrigation model for greens (turnip and mustard) is represented by the equation:

$$
\begin{gathered}
0.5(a-3) \times 0.5 A S W=D_{a-1}+ \\
{\left[E_{p}\left(0.365+0.0154 a-0.00011 a^{2}\right)-\right.} \\
P-I]_{a}
\end{gathered}
$$

where the maximum root depth is 12 inches. The irrigation model for muskmelon is represented by the equation:

$$
\begin{gathered}
0.5(a-4) \times 0.5 A S W=D_{a-1}+\left[E_{p}(-0.064\right. \\
\left.\left.+0.025 a-0.0002 a^{2}\right)-P-1\right]_{a}
\end{gathered}
$$

where the maximum root depth is 16 inches.

Data have been collected to establish daily crop factor values for broccoli, cauliflower, lima bean, onion, pepper, and southern pea.

M odel validation. The snap bean irrigation scheduling model was validated under solid-set and center-pivot irrigation systems in 1980 (Smittle and Johnson, 1982). A line-source irrigation system, as described by Bauder et al. (1975) and Hanks et al. (1976), was used to verify the snap bean irrigation scheduling model in 1985 and 1986. The line-source irrigation system consisted of a single line of sprinklers spaced 20 feet $(6.1 \mathrm{~m})$ apart to provide uniform water application parallel to the irrigation line and continuously decreasing water application with increasing distance from the irrigation line.

The same general cultural practices were used in 1985 and 1986. A rye cover crop was incorporated to a depth of 6 inches $(15 \mathrm{~cm}$ ) before moldboard plowing to a depth of 12 inches $(30 \mathrm{~cm})$. Fertilizer at $(\mathrm{lb} / \mathrm{acre}) 25 \mathrm{~N}$, 21P, 152K (28kg N, $24 \mathrm{~kg} \mathrm{P}, 170 \mathrm{~kg}$ $\mathrm{K} / \mathrm{ha}$ ) and phenamiphos at $6.0 \mathrm{lb}$ a.i./ acre $(6.7 \mathrm{~kg}$ a.i./ ha) were incorporated to a depth of 4 inches $(10 \mathrm{~cm}$ ) immediately before seeding. 'Greencrop' snap beans were seeded 1.5 inches (3.8 $\mathrm{cm})$ apart in 36-inch $(91-\mathrm{cm})$ rows on 6-foot (183-cm) beds on $10 \mathrm{Apr} .1985$ and $25 \mathrm{Mar}$. 1986. Metalochlor at 2.9 lb a.i./ acre (3.2 kga.i./ ha) wasapplied to the soil surface immediately after seeding and was incorporated with 0.5 inch $(13 \mathrm{~mm})$ of irrigation. The $\mathrm{N}$ sidedress was split, with half applied at expansion of the first trifoliate leaf and the remainder at expansion of the fourth trifoliate leaf. Sidedress rates in 1985 were $50 \%, 75 \%, 100 \%, 125 \%$, and $150 \%$ of the recommended total $\mathrm{N}$ rate of $100 \mathrm{lb} /$ acre (112 $\left.\mathrm{kgžha}^{-1}\right)$ for Georgia. Total N rates in 1986 were $50 \%, 100 \%$, and $150 \%$ of the recommended rate (Granberry et al., 1986).

Split-plot designs with five $\mathrm{N}$ rates and two replications and three $\mathrm{N}$ rates and four replications were used in 1985 and 1986, respectively. The $\mathrm{N}$ plots were $20 \times 48$ feet $(6.1 \times 14.6 \mathrm{~m})$ with seven irrigation depth plots within each $\mathrm{N}$ plot. The irrigation depth plots were 20 feet $(6.1 \mathrm{~m})$ of a bed 6 feet $(1.83 \mathrm{~m})$ wide. The beds were parallel to the irrigation line, and irrigation amounts decreased as distance from the irriga 
tion line increased. The irrigation line was placed on a central guard bed and the third bed from the line received irrigation according to the model. The amounts of water applied to each bed on both sides of the irrigation line were measured at each irrigation. Soil water tensions at 6 inches ( $15 \mathrm{~cm}), 12$ inches $(30 \mathrm{~cm})$, and 18 inches $(46 \mathrm{~cm})$ in the first, third, fifth, and seventh beds were monitored with cylindrical gypsum block sensors using a Delmhorst Model KS-1 meter.

Plants from 5 feet $(1.52 \mathrm{~m}) \times 6$ feet $(1.83 \mathrm{~m})$ areas of each plot were re moved, counted, and weighed. Pods were removed and a $2-\mathrm{lb}(0.9-\mathrm{kg})$ sample was graded to remove nonmarketable pods, and marketable pods were weighed.

Data were analyzed by regression analyses using the general linear models procedure of SAS (SAS Institute, 1982).

\section{Results and discussion}

For ease of use and record-keeping, a tabular format, with column headings of age, root depth, date, $E_{p}$, crop factor, daily water use, cumulative use, allowable use, irrigation, and rainfall was used. In this format, data for age, root depth, crop factor, and allowable use were calculated when the table was developed. Data entries for 15- to 30-day-old snap beans are presented in Table 1. On 9 A pr. 1986, data for date and $E_{p}$ ( 0.18 inch) were entered. The value for $E$ was multiplied by the crop factor (6.47) to give a daily use of 0.08 inch. The daily use is added to the cumulative use on day 14 (0.09 inch) and the cumulative use value of 0.17 for day 15 is recorded. The cumulative use value is less than the allowable use; therefore, irrigation was not required on $9 \mathrm{Apr}$. AnE of 0.36 inch on $10 \mathrm{Apr}$. produced a daily water use of 0.12 inch and a cumulative use of 0.34 inch. The cumulative use exceeded the allowable use of 0.30 inch for 16-day-old snap beans; therefore, the snap beans were irrigated with 0.34 inch of water on 10 Apr. Water measurement showed that the model rate plots received 0.35 inch of irrigation. Pan evaporation of 0.24 inch on 11 A pr. produced daily and cumulative water use of 0.12 inch. Daily water use of 0.06 inch and rainfall of 0.10 inch on $13 \mathrm{Apr}$. reduced cumulative water use by 0.04 inch. During this 15-day period when rainfall of 0.10 and 0.05 inch occurred on days 19 and 25 , irrigations with 0.35 , $0.42,0.58$, and 0.72 inch of water were applied on days 16, 21, 26, and 30, respectively.

For a Tifton loamy sand soil having an ASW capacity of 0.1 inch per inch of soil depth, the allowable soil water deficit increased 0.025 inch $(0.64$ $\mathrm{mm}$ ) per day until the maximum al- lowable use of 0.80 inch of water was attained 36 days after seeding. If the model were used for a soil having an ASW of 0.21 inch of water per inch of soil depth, as in Oregon (Mack and Varseveld, 1982), the allowable water use would be $210 \%$ of the values for the Tifton soil. The maximum allowable water use would be $<0.80$ inch if tillage systems (Smittle and Threadgill, 1982) or soil compaction (Smittle and Williamson, 1977) reduced the maximum root depth.

In 1985, the model scheduled six irrigations with a total of 3.94 inches $(100 \mathrm{~mm})$ of water (Table 2). The snap beans received a total of 5.83 inches $(148 \mathrm{~mm})$ of rainfall on seven dates. In 1986, the snap beans intercepted 1.22 inches $(31 \mathrm{~mm}$ ) ofrainfall, with 0.87 inch $(22 \mathrm{~mm}$ ) occurring 49 days from seeding (Table 2). The model called for 11 irrigations totaling 7.72 inches $(196 \mathrm{~mm}$ ) of water (Table 2$)$.

The number of irrigations and the amount of water applied in 1985 and 1986 were less with the model than with the method presently recommended in Georgia. Using Georgia irrigation recommendations of two or three applications of 0.3 to 0.5 inch water/ week (Granberry et al., 1986), 13 to 16 irrigations with a total of 6.5 to 8.0 inches of water would have been applied in 1985 and 15 to 20 irrigations with a total of 7.5 to 9.0 inches of

Table 1. Tabular format of the snap bean irrigation scheduling model $0.05(\mathrm{a}-4) \times 0.5 \mathrm{ASW}=\mathrm{D}_{\mathrm{a} \cdot 1}+\left[\mathrm{E}_{\mathrm{p}}(0.31+0.01 \mathrm{a})-\mathrm{P}-\mathrm{I}\right] a$. ${ }^{2} \mathrm{Soil}, \mathrm{Tifton}$ loamy sand (0.1 inch/inch ASW).

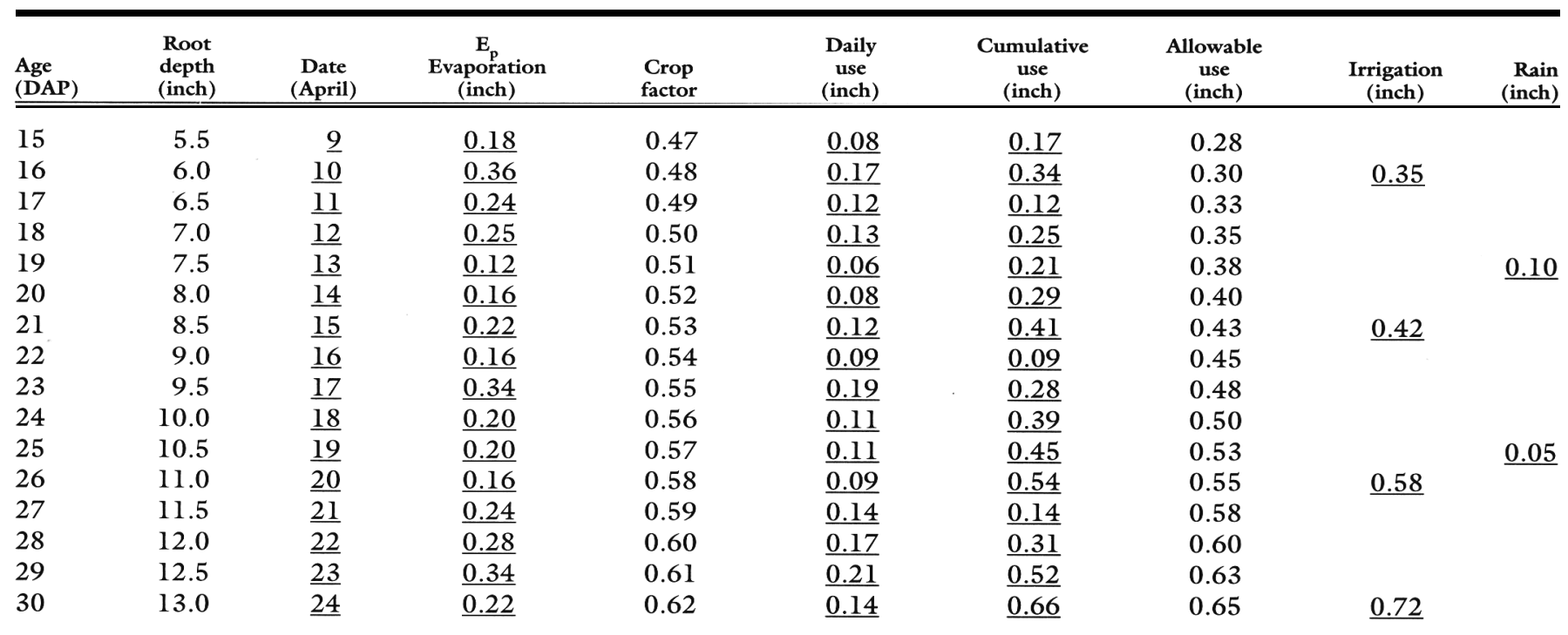

'To operate the model, values for age (a) are recorded; values for root depth are calculated as 0.5(a - 4); valuesfor crop factor are calculated as $0.31+0.01 a$; valuesfor allowable use are calculated as root depth times 0.5A SW; data for date and pan evaporation are recorded; pan evaporation data are multiplied by the crop factor values to calculate daily use; daily use value is added to previous day's cumulative use; and data for today irrigation and rainfall are subtracted from today cumulative use. Irrigation is applied when cumulative use approximates allowable use. 
Table 2. W ater application rates to 'G reencrop' snap beans.

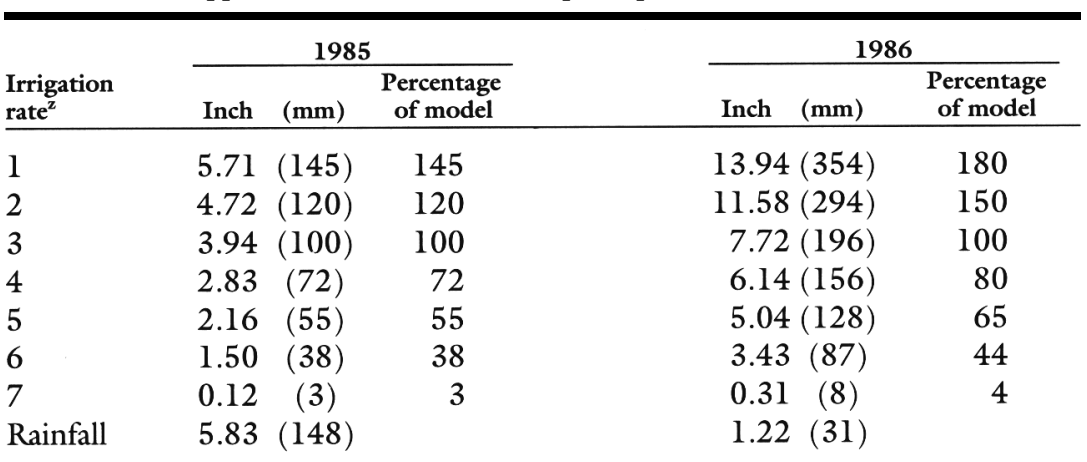

${ }^{2}$ A Il plots received an additional 0.50 inch $(13 \mathrm{~mm})$ of irrigation after seeding Irrigation rate 3 was determined by the irrigation scheduling model. 0 ther rates reflect water application gradients produced by the line-source irrigation system.

water would have been applied in 1986. The line-source irrigation system provided irrigation amounts ranging from $4 \%$ to $180 \%$ of the model.

In 1986 , irrigation at $100 \%$ of the model rate maintained the soil water tension at the 6-inch $(15-\mathrm{cm})$ depth below $25 \mathrm{cb}$ unless the cumulative water use exceeded the allowable use (Table 3). The cumulative water use at the time of irrigation exceeded the allowable use by 0.11 inch $(2.6 \mathrm{~mm})$, 0.13 inch (3.2mm), and 0.21 inch (5.1 $\mathrm{mm}$ ) on days 39,47 , and 54 , respectively. Excessive cumulative uses of 0.13 inch and 0.21 inch on days 47 and 54 resulted in soil water tensions of $46 \mathrm{cb}$ and $133 \mathrm{cb}$, respectively, when water was applied at the model rate. On day 46 , the model showed a cumulative use of 0.71 inch ( $18 \mathrm{~mm}$ ) of water. On this date, the soil water tension at the 6-inch depth was $18 \mathrm{cb}$. With an allowable use of 0.80 inch of water, irrigation could have been applied, but it was not applied until day 47 , to check the response to the model. The model called for an irrigation (0.77-inch cumulative use) on day 53. The soil water tension at the 6-inch depth was $34 \mathrm{cb}$ on this day, but high wind required that irrigation be de layed 1 day to assure a uniform water application gradient with the linesource system. This delay resulted in the 133-cb water tension on day 54. These results and soil water tensions $<25$ cb when the cumulative water use did not exceed the allowable use indicate that the model was effective in scheduling snap bean irrigations.

When water was applied at $180 \%$ of the model rate, soil water tension at the 6-inch soil depth exceeded $25 \mathrm{cb}$ only on day 54. The soil water tension at the 6-inch depth exceeded $25 \mathrm{cb}$ at all irrigations when $\leq 65 \%$ of the model rate of water was applied.

In 1985, pod yield was higher, but marketable yield was little affected with water application rates $>100 \%$ of the model (Table 4). Water application rates greater than the model increased lodging of the plants and increased the nonmarketable pods due to decay. Total and marketable pod yields were lower when irrigations were applied at less than the model rate. Water application rates substantially less than the model also increased the percentage of nonmarketable pods.

In 1986, total and marketable pod yields were lower when water application rates were either greater or less than the model rate (Table 4). The magnitude of the yield response differences to irrigation rates in 1985 and 1986 was attributed to variations in total water intercepted by the crops. Total water (rainfall plus irrigation) intercepted by the snap beans ranged from $63 \%$ to $117 \%$ of the model rate in 1985 and from $22 \%$ to $166 \%$ of the model rate in 1986.

Pod yields were not affected by $\mathrm{N}$ fertilization in 1985, but in 1986 total $\mathrm{N}$ application of 50,100 , and $150 \mathrm{lb} /$ acre produced marketable pod yield of 2.1, 2.7, and 2.9 tons/ acre, respectively, when averaged across all irrigation rates. Maximum response to all $\mathrm{N}$ rates occurred when irrigation was applied at the model rate. Marketable

Table 3. Rainfall and irrigation applied and soil water tensions during growth of 'G reencrop' snap beans in 1986.

\begin{tabular}{|c|c|c|c|c|c|c|c|c|}
\hline \multirow[b]{2}{*}{ DAP } & \multicolumn{2}{|c|}{ Water use (inch) } & \multicolumn{2}{|c|}{ Water applied (inch) } & \multicolumn{4}{|c|}{ Irrigation (\% of model) } \\
\hline & Allowable & Cumulative & Rainfall & Irrigation $^{2}$ & 180 & 100 & 65 & $\mathbf{0}$ \\
\hline & & & & & \multicolumn{4}{|c|}{ Soil water tension $(c b)^{y}$} \\
\hline 14 & 0.19 & 0.25 & 0.08 & 0.25 & --- & --- & --- & --- \\
\hline 16 & 0.26 & 0.34 & --- & 0.35 & --- & --- & --- & --- \\
\hline 19 & 0.34 & 0.23 & 0.10 & --- & --- & --- & --- & --- \\
\hline 21 & 0.40 & 0.41 & --- & 0.42 & --- & --- & --- & --- \\
\hline 25 & 0.51 & 0.45 & 0.05 & --- & 17 & 18 & 27 & 32 \\
\hline 26 & 0.54 & 0.54 & --- & 0.58 & 16 & 16 & 34 & 119 \\
\hline 30 & 0.66 & 0.66 & --- & 0.72 & 16 & 15 & 42 & 118 \\
\hline 36 & 0.80 & 0.87 & --- & 0.89 & 19 & 21 & 49 & 148 \\
\hline 39 & 0.80 & 0.91 & --- & 0.95 & 16 & 22 & 28 & 210 \\
\hline 43 & 0.80 & 0.81 & --- & 0.88 & 18 & 18 & 57 & 210 \\
\hline 47 & 0.80 & 0.93 & --- & 0.99 & 24 & 46 & 57 & 210 \\
\hline 49 & 0.80 & 0.34 & 0.86 & --- & 18 & 18 & 17 & 12 \\
\hline 54 & 0.80 & 1.01 & --- & 0.99 & 91 & 133 & 137 & 55 \\
\hline 56 & 0.80 & 0.12 & 0.17 & --- & 18 & 18 & 17 & 127 \\
\hline 59 & 0.80 & 0.71 & --- & 0.70 & 22 & 23 & 29 & 139 \\
\hline
\end{tabular}

Irrigation depth applied by the model rate (100\%).

${ }^{y}$ Soil water tension measured at 6-inch $(15-\mathrm{cm})$ depth. 
Table 4. Yield and quality responses of 'G reencrop' snap beans to irrigation rates.

\begin{tabular}{|c|c|c|c|c|}
\hline \multirow{3}{*}{$\begin{array}{l}\text { Irrigation } \\
\text { rate }^{\mathbf{z}}\end{array}$} & \multicolumn{4}{|c|}{ Pod yield (tons/acre) } \\
\hline & \multicolumn{2}{|c|}{ Total } & \multicolumn{2}{|c|}{ Marketable } \\
\hline & 1985 & 1986 & 1985 & 1986 \\
\hline 1 & 5.7 & 3.3 & 4.6 & 2.3 \\
\hline 2 & 5.2 & 4.7 & 4.5 & 3.7 \\
\hline 3 & 5.2 & 5.0 & 4.5 & 4.0 \\
\hline 4 & 4.7 & 4.8 & 4.0 & 3.5 \\
\hline 5 & 4.4 & 4.0 & 3.5 & 3.0 \\
\hline 6 & 4.1 & 2.8 & 3.3 & 1.6 \\
\hline 7 & 3.3 & 0.5 & 2.7 & 0.2 \\
\hline Significance $^{\mathrm{y}}$ & $\mathrm{L}^{\star \star} \mathrm{Q}^{\star *}$ & $\mathrm{~L}^{\star \star} \mathrm{Q}^{\star *}$ & $\mathrm{~L}^{* *} \mathrm{Q}^{* *}$ & $\mathrm{~L}^{* *} \mathrm{Q}^{\star *}$ \\
\hline
\end{tabular}

Irrigation rate 3 was determined by the irrigation scheduling model. Rates 2 and 1 represent progressively greater water applications, and rates 4, 5, 6, and 7 represent progressively smaller water applications by a line-source irrigation system (see Table 1 ).

'Linear $\left(\mathrm{L}^{* *}\right)$ and quadratic $\left(\mathrm{Q}^{*}\right.$ ) significant at $\mathrm{P}=0.01$.

pod yields with the model irrigation rate and $\mathrm{N}$ rates of 50,100 , and $150 \mathrm{lb}$ $\mathrm{N} /$ acre were $3.1,4.3$, and 4.6 tons/ acre, respectively. Both maximum yield and the magnitude of the $\mathrm{N}$ response were lower when the irrigation rate was greater or less than the model rate.

The irrigation model for summer squash was tested under a line-source irrigation system during Spring 1986, 1987 , and 1989. With rainfall representing about one-fourth of the total water applied at the model rate, marketable fruit yields of 'Dixie' summer squash showed both a linear and a quadratic response to the irrigation rates produced by the line-source irrigation system (Table 5). Marketable fruit yields were maximized when irrigation was applied at the model rate. Soil water tensions exceeded $25 \mathrm{cb}$ at only one date when irrigation was ap-

Table 5. Effect of irrigation rates on yield of 'Dixie' summer squash and 'Jewel' sweetpotato.

\begin{tabular}{|c|c|c|c|c|c|}
\hline \multicolumn{3}{|c|}{ Dixie summer squash $^{\mathrm{z}}$} & \multicolumn{3}{|c|}{ Jewel sweetpotato } \\
\hline \multicolumn{2}{|c|}{$\begin{array}{c}\text { Irrigation rate } \\
\end{array}$} & \multirow{2}{*}{$\begin{array}{c}\text { Marketable } \\
\text { yield } \\
\text { (tons/acre) }\end{array}$} & \multicolumn{2}{|c|}{ Irrigation rate } & \multirow{2}{*}{$\begin{array}{c}\text { Marketable } \\
\text { yield } \\
\text { (tons/acre) }\end{array}$} \\
\hline $\begin{array}{l}\text { Percentage } \\
\text { of model }\end{array}$ & Inches & & $\begin{array}{l}\text { Percentage } \\
\text { of model) }\end{array}$ & Inches & \\
\hline 148 & 11.4 & 12.3 & 177 & 19.5 & 10.9 \\
\hline 127 & 9.8 & 13.6 & 166 & 18.3 & 10.3 \\
\hline 100 & 7.7 & 14.4 & 143 & 15.7 & 9.6 \\
\hline 86 & 6.6 & 13.6 & 121 & 13.3 & 10.2 \\
\hline 69 & 4.9 & 11.5 & 100 & 11.0 & 10.2 \\
\hline 50 & 3.9 & 11.3 & 82 & 9.0 & 9.3 \\
\hline \multirow[t]{5}{*}{6} & 0.5 & 6.6 & 63 & 6.9 & 9.2 \\
\hline & & & 44 & 4.8 & 11.2 \\
\hline & & & 24 & 2.6 & 10.8 \\
\hline & & & 10 & 1.1 & 10.5 \\
\hline & & & 1 & 0.1 & 10.2 \\
\hline \multirow{2}{*}{\multicolumn{2}{|c|}{$\begin{array}{l}\text { Rainfall (inches) } \\
\text { Significance }^{x}\end{array}$}} & 4.5 & & 19.2 & \\
\hline & & $\mathrm{L}^{* *} \mathrm{Q}^{\star \star}$ & & & NS \\
\hline
\end{tabular}

\footnotetext{
'Values for 'Dixie' summer squash are averages of 1986, 1987, and 1989 seasons.

${ }^{y}$ Values for 'Jewel' sweetpotato are averages of 1988 and 1989 seasons.

${ }^{x}$ Linear $\left(L^{* *}\right)$ and quadratic $\left(Q^{* *}\right)$ effect of irrigation rate significant at $\mathrm{P}=0.01$ or nonsignificant (NS).

tively frequent rainfall and to water use from soil profile depths greater than that controlled by irrigation at the model rate.

We have shown that the frequency and depth of irrigation for snap beans can be scheduled effectively with a simple irrigation model. The model maximized marketable pod yield of snap bean in years when rainfall was 1.22 inches $(31 \mathrm{~mm})$ and 5.83 inches $(148 \mathrm{~mm})$ during production of the snap bean crop and with $\mathrm{N}$ fertilization rates ranging from $50 \%$ to $150 \%$ of the recommended rate. The model for summer squash also effectively scheduled irrigations. Sweetpotato did not show a significant yield response to irrigation. Validation of irrigation models for turnip and mustard greens and for muskmelon are not complete at this time.

\section{Literature Cited}

Bauder, J. W., R.J. H anks, and D. W. Jones. 1975. Crop production function determinations as influenced by irrigation and nitrogen fertilization using a continuous variable design. Soil Sci. Amer. Proc. 39:1187-1192.

Bruce, R.R., J.L. Chesness, T.C. Keisling, J.E. Pallas, Jr., D.A. Smittle, J.R. Stansell, and A. W. Thomas. 1980. Irrigation of crops in the southeastern United States: Principles and practices. U.S. Dept. Agr./ SEA Agr. Rev. \&Man. 5-9.

Granberry, D.M., P. Colditz, and W.J. M CLaurin. 1986. Snap bean. Georgia Ext. Circ. 532.

Haise, H.R. and R.M. H agan. 1967. Soil, plant and evaporative measurements as criteria for scheduling irrigation, p. 577604. In: R.M. Hagan, H.R. Haise, and T.W. Edminster (eds.). Irrigation of agricultural lands. Amer. Soc. Agron., Madison, Wis.

H anks, R.J., J. Keller, V.P. Rasmussen, and G.D. W ilson. 1976. Line source sprinkler for continuous variable irrigation crop production studies. Soil Sci. Amer. Proc. 40:426-429.

H ansen, V.E., O. W. Israelsen, and G.E. Stringham. 1980. Irrigation principles and practices. 4th ed. Wiley, New York.

Jensen, M.E. and J.E. M iddleton. 1970. Scheduling irrigation from pan evaporation. Washington Agr. Expt. Sta. Circ. 527.

M ack, H.J. and G. W. V arseveld. 1982, Response of bush snap beans (P haseolus vulgaris L. ) to irrigation and plant density. J. Amer. Soc. Hort. Sci. 107:286-290. 
SA S Institute. 1982. SAS user's guide: Statistics. 1982 ed. SAS Institute, Cary, N.C.

Smittle, D.A., W.L. Dickens, and J.R. Stansell. 1990. An irrigation scheduling model for snap bean. J. Amer. Soc. Hort. Sci. 115:226-230.

Smittle, D.A. and A.W. Johnson. 1982. Effects of management practices on M eloidogyne incognitaand snap bean yield. J. Nematol. 14:63-68.

Smittle, D.A. and E.D. Threadgill. 1982. Response of squash to irrigation, nitrogen fertilization and tillage systems. J. Amer. Soc. Hort. Sci. 107:437-440.

Smittle, D.A. and R.E. W illiamson. 1977. Effects of soil compaction on nitrogen and water use efficiency, root growth, yield and fruit shape ofpickling cucumbers. J. Amer. Soc. Hort. Sci. 102:822-825.

Stansell, J.R. and D.A. Smittle. 1980. Effects of irrigation regimes on yield and water use of snap bean (Phaseolus vulgaris L.). J. Amer. Soc. Hort. Sci. 105:869-873.

Stegman, E.C., J.R. M usick, and J.L. Stewart. 1980. Irrigation water management, $p$. 763-816. In: M.E. Jensen (ed.). Design and operation of farm irrigation systems. Amer. Soc. Agr. Eng., St. Joseph, Mich. 